\title{
Use of proverbs as communicative tool in Ghanaian choral music compositions
}

\author{
Joshua Alfred Amuah \\ Senior Lecturer \\ Department of Music \\ University of Ghana \\ Legon \\ Email: jamuah@ug.edu.gh \\ Hilarius Mawutor Wuaku \\ Lecturer \\ Department of Music \\ University of Ghana \\ Legon \\ Email: hwuaku@ug.edu.gh
}

Submitted: June 28, 2018 / Accepted: March 27, 2019 / Published: October 4, 2019

\begin{abstract}
This paper first of all identifies Ghanaian composers who explore proverbs as textual materials in their composition. It then proceeds to analyse how proverbs are deployed as communicative tools against the backdrop of Ghanaian cultural sensibilities. The paper further examines the effectiveness of these proverbs from the viewpoint of audience perception and reception. Methodology was based on a search from archives of selected composers and libraries to unravel compositions that use proverbs as the source of text. Audiences were interrogated on their perceptions about such choral works. The research has shown that the use of proverbs in choral music promotes effective communication as well as contributes to the sustainability of Ghana's rich traditional way of communication.
\end{abstract}

Keywords: Proverbs, Ghanaian choral music, communication, Ghanaian composers, composition 


\section{Introduction}

In Ghana, Choral music has been in existence since the pre-colonial era and has been used effectively in day to day social activities. Activities such as funerals, rites of passage, plays, festivals and storytelling have explored choral music. Choral art music in its strictest sense is the exploration of indigenous African music elements and applying them to Western compositional techniques. Dor (2005:443) states that "the Ghanaian choral art idiom since the 1930 can be described as a symbiosis of traditional African music and Western art music. Ghanaian composers have sought not only to situate their songs in the broader social, cultural, and political landscapes of their nation, but also to use indigenous materials and creative procedures that redefine their identity as African composers". Proverbs in the pre-colonial era have been an integral part of most activities that explore choral music since it is known among Ghanaians that proverbs sweeten speeches. However, its scholarly work on use of proverbs in choral music remains relatively few if not non-existent. The only readily available study on the use of proverbs in Ghanaian music is Agyekum (2005). It is a study of the use of proverbs in Ghanaian popular music, specifically on Alex Kwabena Konadu as an Akan oral artist, using his song obi abawuo tuatua obi aso (the death of one's child disturbs another) as an example. This paper builds on Agyekum (2005) by examining the use of proverbs in Ghanaian art choral music as a way to fill this missing gap in Ghanaian musicology.

Since choral music has been an integral part of day to day activities, the use of proverbs in them will instil, and improve the learning and usage of our rich traditional oral culture, which seems to have fallen off from the current generation of Ghanaians. Beside this, choral music which has become ubiquitous by the proliferation of youth choirs all over the country will encourage the younger generation to learn proverbs better and faster than in speech, written texts and in pictures, because in speech, proverbs are explored when there are issues involving the elderly, on written texts, only when one happens to read. Finally, proverbs in pictures could portray varied interpretations since there are no texts to speak to the meaning. The meaning of proverbs remains the same in singing and in speech. The difference in usage either in singing or in speech, as stated earlier, is the fact that the younger ones participate in its usage because they are always performing choral music, but they are not always using proverbs in speech since it is envisaged as the preserve of the elderly. 
Amuah, J.A. \& Wuaku, H.M. / Use of proverbs as communicative tool in Ghanaian choral music compositions

Amuah (2012) suggests four generations of choral music composers. With this as a guide, the selection of items was made from all the four generations. The following composers were selected at the end of the search. In the first generation, Emmanuel Kwasi Aggor's piece was identified as a text with proverbs. In the second generation, pieces from Michael Amissah, Augustine Adu Safo and Walter Blege were recognised. In the third generation, George Worlasi Kwasi Dor's piece had proverbs and in the fourth generation, Sam Asare Bediako's pieces were identified.

\section{Methodology}

The data for this paper were based on interviews and library search for materials on choral music that explore proverbs from composers in Ghana and the outside world. We also searched for most performed choral items by Ghanaians that have proverbs, and collected them from different generations of Ghanaian choral music composers. We searched for these songs from the composers themselves, YouTube and from the gramophone record library at the Ghana Broadcasting Corporation. We also participated in the teaching/ rehearsal sessions with the choral ensemble of the Department of Music, University of Ghana, Legon, and the Harmonious Chorale, Ghana, where varied choral items including items with proverbs are taught and learned to ascertain how students and members respectively react to choral pieces with proverbs.

We recorded, transcribed, translated, and analysed six (6) choral pieces that have proverbs, from the Akan and the Ewe communities, with the view of determining how the pieces effectively communicate to choral music enthusiasts and the masses. We attended performances which presented choral music with proverbs to realise the audience reception and perception. A couple of members from the two choral groups and audiences after performances of choral works were interviewed about their perceptions on such pieces. These include the students, lecturers, elders, middle aged and the teens, all of mixed gender and diverse academic backgrounds. Libraries in the University of Ghana, Legon, including those of the Departments of Music, Linguistics, and the Institute of African Studies and the Balme library were our search libraries for relevant information.

This paper is multi-sectional in structure, and encompasses four broad sections; an introduction, exploration of proverbs and choral music, choral music composers as oral artists and proverbial themes in Ghanaian choral 
music compositions. The introduction comprises the methodology that was employed for the research, the theoretical and conceptual frameworks. The exploration section provides a record of literature related to this study, and biographical sketches of selected composers that have been chosen to precede the analysis of the text of selected works.

\section{Theoretical framework}

Scudder (1980) propounded the theory of communication which says that communication is simply the process of transferring information from the sender to the recipient where the recipient decodes the information and acts accordingly. This paper is based on the basic theory of communication which states that a message emanates from a source, passes through a channel and received and decoded at a destination. Between the source and the destination there could be interferences which distort the intended message. For effective communication to take place, there must be a feedback mechanism from the destination that the message was received and decoded correctly or incorrectly. In the context of this paper, the source of the message is the proverbs in the compositions which is sent through songs in a performance to a target audience who decode the message(s). It is actually the audience that determines whether the message in the proverb from the source is received and understood as intended by the composer and as performed by singers and musicians. Between the source and the target, interferences such as audience noise, acoustics of performance venue, sound reinforcement equipment etc., could all distort the message and prevent effective communication.

\section{Proverbs in Akan: An exploration}

Agyekum (2005:9) posits that "proverbs are interpretations of traditional wisdom based on the experiences and socio-political life of our elders. The most acknowledged element of communicative competencies of an Akan speaker is his/her ability to use $\varepsilon b \varepsilon$ (proverbs)". This implies that a competent Akan composer is the one who usually explores proverbs in his/ her compositions.

In the Akan context, there are adages such as $\varepsilon b \varepsilon$ ne skasamu abohenmmaa, (the proverb is the most precious stone of speech), ctwa ascm tia, (it curtails matters) $\varepsilon$ nka ascm ho a $\varepsilon n n w i e ~ d \varepsilon y \varepsilon$, (without it, a speech does not acquire sweetness). Yankah (1989) on another dimension declares 
that the proverb is a broad concept and instances, and encompasses both malicious and benign uses of indirectness (Yankah 1989b: 109-111). In all these instances, there is the indigenous perception of the proverb as an aesthetic device of vitality in speech and also as an indispensable aspect of speech. (Agyekum 2005) considers proverbs as the salt of a language, without which the real taste of the language dish is not felt. The relevance of these short sayings is clear. Proverbs are a rich source of imagery. The proverb is a succinct expression on which more elaborate forms can be drawn. (Finnegan 2012: 379).

The value of the proverb to people in modern day Ghana does not lie only in what it reveals of the thoughts of the past. For the speaker and the oral artist, the proverb is a model of compressed or forceful language. In addition to drawing on it for its words of wisdom, the Akan or Ewe speaker takes interest in its verbal techniques (its selection of words) and comparison as a method of statement. Familiarity with its techniques enables the oral artiste to create his own proverbs. This enables him to avoid hackneyed expressions and give a certain amount of freshness to his speech.

According to Owusu Brempong (2014: 147), "the use of proverbs is not only to mark the elegance in speech but also phrases the philosophy and the poetry of the Akan people. For example, folk songs, funeral dirges and other lamentations, ceremonial songs, adawu (court) songs and dances draw on immense store of proverbs for the theme, imagery and the morals of the Akan”. He emphasizes that proverbs do not belong to any particular person. They are traditional knowledge, often attributed to elders and ancestors. Old people are assumed to have more experience and know more about the Akan world than the young people, who are not close to their ancestors. Proverbs, are thus, words of wisdom from ancient times.

The employment of proverbs in the speech of accomplished speakers or oral artists makes the proverbs not only a body of short statements and a reflection of thought and insight of Ghanaians into problems of life, but also a technique of verbal expression, which is greatly appreciated by the Ghanaian. It is no wonder therefore that the use of proverbs has continued to be a living tradition in Ghana (Nketia 1978:21).

From the above discussion, it is evident that proverbs provide interpretations of traditional wisdom based on the experiences; it comprises malicious and benign uses of indirectness. This implies that choral compositions embedded with proverbs equally provide same benefits as in the spoken language. That accounts for why choral composers resort to 
spicing their compositions with proverbs. However, even though proverbs have been extensively used in choral compositions, no scholarly writings seem to address this issue. This paper therefore discusses some choral compositions that have explored proverbs in them to display the potency of proverbs.

\section{Choral music: A survey}

Dor (2005) in his paper "Uses of Indigenous Music Genres in Ghanaian Choral Art Music: Perspectives from the Works of Amu, Blege, and Dor" discusses three selected art choral works, Yaanom Abibirim mma ("Fellow Black Africans") by Ephraim Amu, Ese ye do Ame da ("The Creator God Sends People with Unique Gifts") by Walter Blege, and Agbemavo Minyam Miele ("We are Aiming at Eternal Life") by himself. This paper aims at illustrating the ways in which these representative Ghanaian composers have used indigenous music genres in their works as pre-compositional resources. Dor (2005), further indicates that the similarities in the uses of re-invigorated genres in the three selected works make them archetypes and perfect for the discussion. Although Dor explores the use of indigenous music, his work does not principally include the use of proverbs. In his work, it was evident that he has explored proverbs but does not deepen the discussion on them since that was not the central theme of the paper.

Terpenning (2017) in his Ph.D dissertation discusses "Choral Music, Hybridity, and Postcolonial Consciousness in Ghana”. In that study he indicates that Ghanaian choral music developed from the colonial experience through a process of musical hybridity and became relevant in the postindependent state of Ghana. The dissertation in no other circumstance makes reference to proverbs.

Gbolonyo (2009) in his PhD dissertation on "Indigenous knowledge and cultural values in Ewe musical practice: their traditional roles and place in modern society" examines the aspects and functions of Ewe indigenous knowledge system, values, and musical practice. The general objective of the study is to help policy makers to create and promote awareness of the use of indigenous knowledge and values among Ewe youth and scholars. It explores Ewe indigenous knowledge and cultural values rooted in Ewe musical practices and discusses the extent to which musical practice preserves and transmits them. Even though proverbs constitute an integral part of indigenous knowledge systems the project seems to be silent on it. This gap, so identified in the above stated attempts offer the opportunity to 
Amuah, J.A. \& Wuaku, H.M. / Use of proverbs as communicative tool in Ghanaian choral music compositions

delve deep into the use of proverbs in choral music in contribution to the application of indigenous knowledge system in contemporary Ghana.

\section{Composers and performers as oral artists}

Agyekum (2005:3) states that "oral artists in Akan include singers and composers, poets, dirge singers, etc." They have major social roles to play in almost all the important occasions in our life from cradle to grave. One of the most important scenarios for oral performance in Akan and Ewe communities is during funeral ceremonies where many traditional orchestras like the adowa, kete, nnwonkors, apatampa, adenkum, osoode and bəsoe, (in the Akan-speaking areas), and agbadza, bəbəэbว, gahu, avihawo, and egbanegba (in the Ewe-speaking areas) among others perform choral pieces of the composers whose works are selected for this paper are also performed at funerals, especially at burial services in the church. This implies that choral music composers are oral artists and can be recognised from the same perspectives. Choral music composers should therefore be regarded as oral artists because African/Ghanaian composers sometimes borrow from oral traditions with the inclusion of proverbs.

Oral artists receive traditions and cultural training from the society and the cultural set up and interpret them in their own experiences and situations; hence, there is a continuity of tradition. In the first place, the language used for the composition belongs to the society. (See Agyekum 2005) A work becomes popular and acceptable if many people understand the language, its symbolism and can decode the message. Oral artists have at their disposal, stocks of tradition including phrases, proverbs, idioms, allusions and other stylistic devices and techniques of composition that they adopt from older artists and reshape them to suit current situations and times (see Finnegan, 2012:60; Bauman, 1986:8).

Agyekum (2005) again states that the most outstanding oral artists are the praise singers at the various traditional courts. They perform when a king is appearing in public, when he sits in public for his subjects to pay homage and when he is leaving the place. Akan kings and chiefs had court poets and praise singers who helped to maintain the powers and images of these rulers. They could use their poetry and praises to advise and caution the rulers about crucial issues that may affect their regimes. They could draw the attention of the kings to some of the improprieties of their regimes. This is not different from what choral music performers do. We believe it is because they fall under the purview of oral artists. Choral music performers, 
especially those who perform for church activities perform very similar roles. They perform when a pastor is appearing in the pulpit to preach and also when any dignitary is about to speak in the church and in the public domain.

\section{Use of proverbs in Ghanaian choral Art Music compositions}

Clayton (1996:27), opines that, "a theme is a central idea upon which a creative work is designed. It gives a clue as to how the artist should proceed with his work. The theme is the triggering factor that controls all the expressive choices of a literary artist". With respect to the selected composers, the themes of their works hover around patriotism and nationalism. This implies that the text of their pieces hinge on love and the development of one's nation, and the use of folk elements and nationalism in music.

In the first piece by Emmanuel Aggor, Maalee maalee dii wotsic (I will bath, I will bath,leaves you in dirt) speaks to procrastination. In the second piece by Walter Blege, Nunya Adidoe (Knowledge is the baobab), he dilates on selfishness and sharing or collaboration. The third piece by Augustine Adu Safo also concentrates on procrastination; the fourth, Susu w'ascm kyere by Michael Amissah focusses on sharing and collaboration. The fifth item Megati nusikowu wo la yome o (Be content with what you have) by George Dor emphasises that one needs to be content with what one has. Finally, the sixth piece, $\mathrm{Na}$ aden? (And why?), by Asare Bediako concentrates on patriotism.

\section{Songs with proverbs}

This section presents songs by the selected composers which have proverbs in them. The songs provide the Akan/Ewe texts and their translations in English and identify the proverbs in the songs. We have demarcated proverbs from the entire texts by italicising and bolding at the right side of the translations to enable easy referencing.

Quite a number of researches have been done on the first and the second generations on the use of traditional music elements in Ghanaian choral music compositions. The following choral pieces from the selected composers have been chosen for this study, representing all four (4) 
Amuah, J.A. \& Wuaku, H.M. /Use of proverbs as communicative tool in Ghanaian choral music compositions generations in choral music composition in Ghana.

\begin{tabular}{|c|c|c|c|}
\hline Title of Song & English Translation & Composer & Generation \\
\hline $\begin{array}{l}\text { Maalee, Maalee, Dii } \\
\text { Wotsic }\end{array}$ & $\begin{array}{l}\text { (I will bath, I will bath, } \\
\text { leaves you in dirt) }\end{array}$ & Emmanuel Aggor & $1^{\text {st }}$ \\
\hline Nunya Adidoe & $\begin{array}{l}\text { Knowledge is the } \\
\text { baobab }\end{array}$ & $\begin{array}{l}\text { Walter Kəmla } \\
\text { Blege }\end{array}$ & $2^{\text {nd }}$ \\
\hline Kokəsakyi & Vulture & $\begin{array}{l}\text { Augustine Adu } \\
\text { Safo }\end{array}$ & $2^{\text {nd }}$ \\
\hline Susu ho Kyere & Share with others & $\begin{array}{l}\text { Michael K. Amis- } \\
\text { sah }\end{array}$ & $2^{\text {nd }}$ \\
\hline $\begin{array}{l}\text { Megati Nusi Kэwи Wo } \\
\text { La Yome o }\end{array}$ & $\begin{array}{l}\text { Be content with what } \\
\text { you have }\end{array}$ & George W. K. Dor & $3^{\text {rd }}$ \\
\hline Na aden? & And why? & Sam Asare Bediako & $4^{\text {th }}$ \\
\hline
\end{tabular}

In all, six (6) compositions were realised; one from the first generation, three for the second generation, one for the third generation, and one for the fourth generation. The reason as to why one piece was realised in the first generation will be attributed to the fact that art music compositions had just been begun and the concentration was on what had been received from the missionaries, which was more of hymn writing. The idea to incorporate or blend traditional elements had not taken roots then, and that accounts for that. Even though exploration of indigenous elements in composing had taken roots, dominant composers of the third generation, had less interest in using proverbs which perhaps might be that they had not been nurtured from the traditional roots.

In each of the compositions the composers' brief background is provided followed by the translation of the texts either from Akan/Ewe to English. The proverbs identified in the piece are then indicated followed with a brief musical analysis, an analysis of the texts and the proverbs.

\section{Maalee, Maalee, Dii Wotsie (I Will Bath, I Will Bath, Leaves You In Dirt) Emmanuel Kwasi Aggor}

This was written by Emmanuel Kwasi Aggor (1908-1999). Born in Peki Avetile on November 22, 1908, Emmanuel Kwasi Aggor, known popularly as Catechist Aggor, trained as a teacher in the Akropong Teacher Training College from 1927 to 1930 where he was also taught by the legendary Dr. Ephraim Amu. Emmanuel Aggor has over fifty (50) choral works to his credit, some of which used to be constantly aired on Radio 
Ghana. His works include choruses for Soprano, Alto, Tenor, Bass, and solo voices. Generally, his compositions are not contrapuntal. He hardly uses a harmonic vocabulary beyond the chord of the $7^{\text {th }}$ (Agordoh, 2011). One of his extended solo works is Maalee, Maalee, Dii Wotsie. This is discussed here in relation to the use of proverbs which dilate on the popular adage that procrastination is the thief of time.

The proverb, Maalee, maalee, dii Wotsic (I will bath, I will bath, leaves you in dirt), as represented in the title of the song stands out as the main theme - procrastination is the thief of time - around which the composer builds his story line. The haunt of one's own inaction becomes an unbearable burden if care is not taken. This is the lesson the composer draws on in the proverb "procrastination is the thief of time" as stated earlier. As clearly spelt out in the song text in the appendix No. 1, the composer begins to tell his story about the velvet bean seed, a very dangerous plant that itches strongly when it gets in contact with the body when dried. This, he noticed right from the onset when it germinated at his backyard. He had planned to uproot it since but kept postponing till it got fully grown and dried up to the extent that it became a no-go area in his own backyard.

The story continued with that allusion; he kept postponing attending to a friend's call for him to come and listen to a matter that concerned himself. The next thing he heard was the death of that friend. That eventually set him in a serious state of confusion and imbalance and continued to be a burden that has arisen as a result of his own inaction of procrastination.

The moral lesson here is that procrastination has serious consequence on our future hence there is the need for us to perform our tasks immediately without delays.

\section{Nunya Adidoe (Knowledge is the Baobab)}

Nunya Adidoe (Knowledge is the Baobab) is a composition by Walter Komla Blege. He hails from Kpedze in the Volta Region of Ghana and was born on December 22, 1936. He holds a Bachelor of Arts degree in History (London), Diploma in Education and M.Ed. in Curriculum from the University of Toronto, Canada. In the Evangelical Presbyterian Church at Ho, he played a very significant role in indigenizing Ewe music for Christian liturgy. Blege moved away from composing in the style of his teacher, Nayo, and adopted his own originality in composing by employing traditional musical elements including dance forms, themes, performance, singing style and idioms. Agordoh (2011) revealed that it was during the 
Amuah, J.A. \& Wuaku, H.M. / Use of proverbs as communicative tool in Ghanaian choral music compositions

tenure of office of the late Rev. Noah Dzobo as Moderator of the Evangelical Presbyterian Church (1981-1990) "that he commissioned Blege to write several works including the opera, Kristo, a Drum Prelude as introit and setting, "The Lord's Prayer" to music in traditional gahu dance style.

Nunya Adidoe, is one of the songs composed by Walter Komla Blege who made use of a single proverb in the song. It is a very simple and short song with this proverb which runs through and ending up as the only text of the song - Nunya adidoe, asi me tunco. The song encourages the spirit of collaboration and likens it to the fact that knowledge is like the baobab tree which is so huge, a state in which the arm's length cannot go round it. For steady and speedy progress, the spirit of partnership is key. According to Stevenson, the:

"Baobab (Adansonia digitata) is a tree consisting of nine species native to the dry, hot savannas of Australia, Africa and the island of Madagascar. The tree grows 40 to 75 feet tall and has a trunk measuring 35 to 60 feet in diameter". (Stevenson 2010:130).

Indications are clear from the above that the arm's length cannot go round this tree and so is life performance where we need one another to cooperate in order to accomplish tasks. The proverb admonishes us that knowledge is never and can never be embedded in one person's mind. The fact is that one person does not know it all. It is in the spirit of sharing ideas and collaborative work that progress abounds in an atmosphere of stress, no matter the level of one's expertise, and experience.

\section{Kokssakyi (Vulture) Augustine Adu Safo}

Kokısakyi was composed in 1969 by Augustine Adu Safo. He was born in 1934 and died in 1988. He attended the Akropong Presbyterian Training College now the Akropong Presbyterian College of Education at Akropong from 1952 to 1955, and to the then Specialist College at Winneba and obtained the Licentiate Royal School of Music Certificate in 1966. He taught at the Erstwhile National Academy of Music now the Department of Music Education of the University of Education, and held many positions including the head of the theory unit, conductor of the institutional choir. He also taught at the Musama School of Music and served as the director from 1985 until his death in 1988. He has several choral works prominent of which are Kokssakyi, Iesu Aseda and News.

Adu Safo explores two proverbs in Kokısakyi 
Amuah, J.A. \& Wuaku, H.M./Legon Journal of the Humanities Vol. 30.1 (2019)

\begin{tabular}{|c|c|}
\hline Mmวtohə ує тиsu o & $\begin{array}{l}\text { Procrastination is } \\
\text { dangerous. }\end{array}$ \\
\hline $\begin{array}{l}\text { Wofiri ntem bore nsuo a na wani } \\
\text { bere Mmstoh y y musuo. }\end{array}$ & $\begin{array}{l}\text { If you set off in good } \\
\text { time to swim you } \\
\text { show seriousness. } \\
\text { Procrastination is } \\
\text { dangerous. }\end{array}$ \\
\hline
\end{tabular}

The piece talks about the vulture and its habitual postponement to build a house. It keeps postponing and thinks about building only when there are signs of rainfall. The idea comes to mind only when clouds are formed with thunderstorm, which leads to rainfall. The idea to build dissipates as soon as the gathered clouds, thunderstorms and rains are over.

The two proverbs conclude his preaching on the use of time, and advice that we must with all seriousness attack our goals and accomplish them once we conceive the idea to embark on a project. The more we postpone, the more we are unable to complete the task. The first proverb, procrastination is the thief of time, speaks on the fact that we should not keep postponing the accomplishment of an activity because we will end up not doing it. The second proverb indicates that the earlier we started, the better, and that brings seriousness in what we want to achieve, so we must immediately start and accomplish a task once we conceive the idea to do it.

\section{Susu Ho Kyere (Share with others) By M. K. Amissah}

Susu W'asem kyere is a composition written by Michael K. Amissah. He was born in Aboso in the Western Region of Ghana. He started learning music at a tender age and sang as the soloist in Aboso Catholic church choir. He also joined a fife band at Tarkwa, and eventually became its leader. In 1958, Amissah enrolled at the Kumasi College of Technology to study Music, which led to the award of Associated Board of the Royal School of Music (ABRSM) and Licentiate Diploma London Royal School of Music (LRSM). He went for further studies in Rome leading to the award of a Bachelor's degree in Sacred Music, and Master of Arts Degree in Music (Agordoh, 2005). In the Western Region, he paired with Entsuah Mensah ${ }^{1}$ and formed several Vocal Bands which compelled him to write so many social songs for "wake keeping". One of such songs is Susu ho kyere.

Susu ho kyerc speaks to colleagues who are selfish or secretive, and will never divulge any issue of concern, whether good or bad, to colleagues

${ }^{1}$ A renowned composer and organist of the Methodist Church, an exponent of African rhythms and the use of chromatic notes, whose compositions are difficult to perform. 
for direction, advice or support. Such colleagues usually keep issues to themselves until the inevitable occurs. The proverb Itsir kor mpam means that one head does not go into counselling. In this piece Amissah encourages all to share issues that bother them with a colleague or two because when two heads brainstorm on an issue they arrive at a faster and prudent decision. It is only when you have put your problems before other people that you can receive suggestions on how best to solve them. So we are encouraged to share our worries.

\section{Megati Nusi Kowu wo la Yome o (Be Content with what you have) George Worlasi Kuasi Dor}

Megati Nusi Kowu wo la Yome o (Be Content With What You Have) is a choral piece composed by George Worlasi Kwasi Dor. He was born in Alavanyo Wudidi in the Volta Region of Ghana on the $11^{\text {th }}$ of July, 1954. He took advantage of his favourable musical environment to build his career. He pursued his tertiary education at the University of Ghana up to the Masters level before proceeding to the USA for his PhD in Music. The song, Megati Nusi Kowu wo la Yome o, was composed in May, 1977. The song presents six (6) proverbial expressions, all of which address the stated theme "one needs to be content with what one has". The proverbs are:

\begin{tabular}{|c|l|}
\hline $\begin{array}{c}\text { 1 Megati nusi kowuwo } \\
\text { la fe yoo me oo }\end{array}$ & Do not pursue heights beyond you \\
\hline $\begin{array}{c}\text { 2. Ahloe medoa nyifsk- } \\
\text { pa o de }\end{array}$ & $\begin{array}{l}\text { The antelope does not wear the shoe of } \\
\text { a cow }\end{array}$ \\
\hline $\begin{array}{c}\text { 3. Devi mekaa nyaga o, } \\
\text { akplegae wo kana }\end{array}$ & $\begin{array}{l}\text { A child does not bite big words, it is big } \\
\text { morsel of food he bites }\end{array}$ \\
\hline $\begin{array}{l}\text { 4. Avu du fu me duna ga } \\
\text { o, me duna ga o }\end{array}$ & $\begin{array}{l}\text { A dog does chew bones; it does not } \\
\text { chew metal. }\end{array}$ \\
\hline $\begin{array}{l}\text { 5. Devi gbana abobogo, } \\
\text { megbana klogo o dee }\end{array}$ & $\begin{array}{l}\text { The child breaks the shell of the snail } \\
\text { and not the shell of the tortoises }\end{array}$ \\
\hline $\begin{array}{c}\text { 6. Devi dzroa nu, medz- } \\
\text { roa golo f'azi o }\end{array}$ & $\begin{array}{l}\text { A child curiously yearns for food and } \\
\text { not for the ostrich egg }\end{array}$ \\
\hline
\end{tabular}

The entire text of the song is available in appendix No. 5 .

The text of the song advises that, to eschew violence and social misfit characterised by envy, stealing and murder, among other societal unrests, we need to be content with what we have. As espoused in the text, the composer used proverbial expressions. First of all, in a general statement that one should not pursue heights that one cannot attain as in proverb 
1. The composer proceeded with the antelope and the cow as in proverb 2 above. The antelope is a much smaller animal compared with the cow. There is no way the feet of the antelope can fit into the shoe of the huge legs of the cow. This clearly links up with the composer's main theme that there is no need craving to achieve unattainable heights. There is the need for one to realise one's own capabilities and live within those parameters.

Thirdly, the composer, using the child, draws attention to the fact that there is the need to be mindful of the choice of words. The wrongful use of utterances is much likely to land him and the society in unbearable trouble as against biting and chewing a big morsel of food. The text of the song continues to compare how easy it is for the dog to crack and chew a piece of hard bone but impossible to chew a metal. The bone from meat can easily be cracked and chewed by the dog. On the other hand metal is a substance which a dog can neither crack nor chew.

Similarly, the composer uses proverb 5 in the text, to compare the child's ability to easily break the shell of the snail as against the simple impossibility to break that of the tortoises. Proverb 6 finally draws attention to the fact that the curiosity and yearn for food on the part of the child is not a crime, but venturing into seeking for the egg of an ostrich can be an unattainable request.

The song advises mankind to be content with both physical and spiritual possessions and to operate within their abilities so society will continue to be a peaceful place to live in. Similar proverbs within the Akan culture of Ghana states, "abofra bo nwa na smms akyekyedeع", "abofra te fufuo a ote dec cbeks n'ano" and abofra hen abcn na onnhen wodur (Fante). And such English proverb as, "do not bite more than you can chew", all add to explaining the message which is built around the theme which admonishes one to be content with what one has.

\section{Na Adzn? (And Why?) Samuel K. Asare-Bediako}

Na Adcn? (And why?) was composed by Samuel K. Asare-Bediako, a son to Mr. Christian Asare Bediako and Mrs Rose Asare-Bediako. He had his first music lessons from the parents from age 5 and started playing hymns at the age of 7 . Asare-Bediako was greatly encouraged by his grandparents, Pastor J. K Amoah and Mrs. Mary Boatemaa Amoah. He received his first harmonium organ from the grandfather when he was just eight (8) years old and started composing before high school education. He later had his Diploma in Music Education at the National Academy of Music, Winneba in 
Amuah, J.A. \& Wuaku, H.M. / Use of proverbs as communicative tool in Ghanaian choral music compositions

1986, B.A (Music) at the University of Cape-Coast in 1997 and Diploma in Social Service at Toronto Medix School in 2006.

Asare Bediako explores four proverbs in the song $\mathrm{Na}$ adcn? (And why?):

\begin{tabular}{|c|c|c|}
\hline 1 & Tiri ko nk egyina & It takes two people to tango. \\
\hline 2 & $\begin{array}{l}\text { Dua koro gye } \\
\text { mframa ebu }\end{array}$ & $\begin{array}{l}\text { Isolated tree falls on the least thunder- } \\
\text { storm. }\end{array}$ \\
\hline 3 & $\begin{array}{l}\text { Praee wo ho yi } \\
\text { woyi baako a, na } \\
\text { ebu woka bo mu } \\
\text { a, emmu oo }\end{array}$ & $\begin{array}{l}\text { The broom breaks easily as a single } \\
\text { unit but not possible when they are put } \\
\text { together. }\end{array}$ \\
\hline 4 & $\begin{array}{l}\text { Koroye ma } \\
\text { nkunim }\end{array}$ & Unity brings victory. \\
\hline
\end{tabular}

Together the four proverbs speak to unity. With this, Asare Bediako speaks to Ghanaians to be united since two or more people on a mission usually accomplish tasks successfully. The first proverb, it takes two people to tango, demonstrates this. The second proverb speaks to unity on a different dimension using trees in the forest and admonishes Ghanaians to be united and not stand apart as isolated trees, because the least thunderstorm can fell an isolated tree but a lot of trees in the forests stand firm even with heavy thunderstorm. He relates this to us as human beings that one person could easily be attacked by the enemy but two or more people can face an aggression from the foe. Similarly, the third proverb reiterates the theme of unity and warns us to be united like a number of broom sticks which have been put together, and can never be broken. This suggests that if we come together as a unified force we can stand any violence but if we fight individually we can be defeated. The composer employs the style of semantic parallelism where the implications of the four proverbs are the same.

\section{Abridged musical analysis of selected pieces}

The melodic organisation of the songs with the proverbs follow the speech contour because of the Akan and Ewe languages, which are tonal languages, and are presented as the spoken text. In rhythm, the durational values of the notes correspond to the durational values of the syllables in the text. It therefore aids in transmitting clearly the meaning of the songs. The harmonies employed for these songs are varied. Since the songs are all African/Ghanaian, harmony of thirds and sixths are predominant, and 
are spiced with Western harmonic usages such as the shifting tonality and secondary seventh chords. The texture for the selected compositions is generally homophonic with few instances of monophonic and polyphonic textures. On dynamics, there were instances where the composers use melodic contours, text and harmony to depict dynamic levels they wish to achieve in their works.

\section{Audience appraisal of proverbs as communicative tool}

On interviews conducted among choral music performance audiences, indications were that the use of proverbs to spice the text in choral compositions presented them very natural and also manifested the African nature of the text. Performances looked real as if the text was spoken, and this confirms the orality of Ghanaian traditional discourse. The one or more proverb(s) in a composition summarise(s) the volume of song text that constructs the piece. The audiences also indicated that the message in the proverbs were well understood putting them in the context with which the composers used them. The feedback from audiences after a performance of choral compositions weaved with proverbs portrayed that choral composers who used the style of composing choral works with proverbs have gained wisdom, and are knowledgeable based on experiences or occurrences in our real life situations. They also indicated that choral compositions spiced with proverbs make the compositions "sweet". Finally, audiences showed that the use of proverbs is an aesthetic means of strengthening speech in choral music.

\section{Conclusion}

It has been realised that in choral pieces the proverbs sum up the meaning embedded in the entire piece. This confirms Agyekum's assertion that $\varepsilon b \varepsilon$ twa ascm tia (proverb curtails matters). In the first generation of choral music composers Aggor, in his Maalee, Maalee, dii wotsic, explored only one proverb, yet a huge volume of texts surrounding it in his chain of story line hinge on the proverb. The story leading to the proverb made the meaning very clear.

In the second generation Adu Safo, explores two proverbs: mmotohs

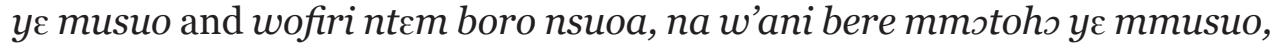
which speak directly to the text. Blege uses only one proverb Nunya Adidoeasi me tuneo, which constitutes the entire song. Amissah explores 
Amuah, J.A. \& Wuaku, H.M. / Use of proverbs as communicative tool in Ghanaian choral music compositions

two proverbs Susu w'ascm kyerc and itsir kor mpam, as part of the text that constructs the entire piece. In all the selected pieces, one or two proverbs in the text summarise(s) the entire piece.

It is generally accepted that the use of proverbs in choral musicenhances the meaning and presents choral music as a word of admonition. The pieces sought further to advising the audience to desist from procrastination or be content with what is due them. Audience indicated that they wish to have had a lot of songs which have proverbs in them, since the younger ones will learn the proverbs, their meanings, and usage in choral music as well as learning them as part of the rich cultural resources of Ghana. 


\section{References}

Adu-Safo, A. (1992). Kokəsakyi (Vulture) Unpublished Manuscript.

Aggor, E. K. (1928). Malee, maalee, dii wotsic (I Will Bath, I Will Bath, Leaves You in Dirt) Unpublished Manuscript.

Agordoh, A. A. (2011). The development of church music in Ghana. Sundel Services, Accra, Ghana.

Agyekum, K. (2005). An Akan oral artist-The use of proverbs in the lyrics of the Kwabena Konadu. Research Review NS 21. (1-17)

Amuah, J.A. (2012). The use of traditional music elements in contemporary choral music compositions: Perspectives form the selected works of GWK Dor, Nicodemus Kofi Badu and Newlove Annan. PhD Thesis, University of Ghana, Legon.

Amissah, M.K. (1982). Susu ho kyere (Share with others) Unpublished Manuscript.

Asare Bediako, S. (1998). N’aden? (But Why?) Unpublished Manuscript. Bauman, R, (1986). Story, performance, Event: Contextual studies of oral narrative. New York: Cambridge University Press.

Blege, W.K. (1974). Nunya adidoe (Knowledge is The Baobab) Unpublished Manuscript.

Clayton, J. J. (1996). The heath introduction of fiction. Lexington: D.C Heath and Company Publishers.

Dor, G.W.K (1977). Megati nusi kowu wo la yome (Be content with what you have).

Dor, G.W.K (2005). Uses of indigenous music genres in Ghanaian choral art music: Perspectives from the works of Amu, Blege, and Dor. Journal of Ethnomusicology 49, (3).

Finnegan, R. (2012). Oral Poetry: Its nature, significance and social context. Bloomington:Indiana University Press.

Gbolonyo, J. S. K (2009). Indigenous knowledge and cultural values in Ewe musical practice: Their traditional roles and place in modern society Unpublished PhD Thesis, University of Pittsburgh, USA.

Nketia, J.H.K. (1978) Amoma. Accra: Ghana Publishing Corporation.

Owusu, Brempong, (2014). Proverbs and proverbial sayings in highlife songs. Journal of Performing Arts. 4 (147-156).

Randel, M (2004) The new Harvard dictionary of music. Cambridge, MA. Belknap Press of Harvard University. 
Amuah, J.A. \& Wuaku, H.M. /Use of proverbs as communicative tool in Ghanaian choral music compositions

Scudder, S. F. (1980). [http://www.managementstudyguide.com/ communication- theory. html retrieved 31/10/17.

Stevenson, A. (2010) Oxford dictionary of English $3^{\text {rd }}$ edition. Oxford. Oxford University Press

Terpenning, S. T. S. (2017). Choral music, hybridity, and postcolonial consciousness in Ghana. PhD Dissertation. University of Colorado. Boulder.

Yankah, K. (1989). 'Proverbs: the aesthetics of traditional communication'. Research in African Literatures2. (2): (325-347). Austin: University of Texas USA. 


\section{Appendices}

\section{Song Texts of Selected Pieces}

Malee, Maalee, Dii Wotsi (I Will Bath, I Will Bath, Leaves You

In Dirt)

\begin{tabular}{|c|c|c|}
\hline Ewe Text & English Translation & Proverb \\
\hline Malee, maalee, dii wotsic & I will bath, I will bath, leaves you in dirt & Proverb \\
\hline Malee, maalee, dii wons & I will bath, I will bath, leaves you in dirt & Proverb \\
\hline $\begin{array}{l}\text { Ne metso de yu kaba wse ne } \\
\text { enyo }\end{array}$ & $\begin{array}{l}\text { It would have been good if I had taken } \\
\text { off early to do it }\end{array}$ & \\
\hline Etsi megbe xoxo & It's already late. & \\
\hline $\begin{array}{l}\text { Etsi megbe hezu fu nam } \\
\text { mele kpckp }\end{array}$ & $\begin{array}{l}\text { It's late and has become a burden am } \\
\text { suffering }\end{array}$ & \\
\hline Awloka de mic de boto & $\begin{array}{l}\text { A certain velvet bean seed sprouted / } \\
\text { geminated at the backyard }\end{array}$ & \\
\hline Nye ytonto wo boto & My own backyard & \\
\hline $\begin{array}{l}\text { Mekpoe kaba, wo dodo de } \\
\text { eyu }\end{array}$ & I saw it early and had planned to act & \\
\hline Mews dodo be mahoe & I planned to uproot it & \\
\hline $\begin{array}{l}\text { Mekpoe kaba, wo dodo de } \\
\text { eyu }\end{array}$ & I saw it early and had planned to act & \\
\hline $\begin{array}{l}\text { Mews dodo be mahoe, } \\
\text { mahoe }\end{array}$ & $\begin{array}{l}\text { I planned I will uproot it, I will uproot } \\
\text { it }\end{array}$ & \\
\hline Afee woava azu tsetsela & Before it develops its seed & \\
\hline Ava zu fufula & Before it gets dried & \\
\hline Mews dodoa pe, edziwsws & $\begin{array}{l}\text { I had really done the plan, but the im- } \\
\text { plementation }\end{array}$ & \\
\hline Etso maahoe, etso maahoe, & $\begin{array}{l}\text { I will uproot it tomorrow, I will uproot } \\
\text { it tomorrow }\end{array}$ & \\
\hline Eya dzi ko mele kaka & Is all I have been on always & \\
\hline $\begin{array}{l}\text { Dutanya de va hem yi } \\
\text { dudefe. }\end{array}$ & $\begin{array}{l}\text { A call came that summoned me to a } \\
\text { distant place }\end{array}$ & \\
\hline Kasia magboi efu xoxo & $\begin{array}{l}\text { Before I returned, it had already dried } \\
\text { up }\end{array}$ & \\
\hline 'Tadodo de tef'aa megalio & No possibility of getting near there. & \\
\hline Kasia magboi efu xoxo & $\begin{array}{l}\text { Before I returned, it had already dried } \\
\text { up }\end{array}$ & \\
\hline
\end{tabular}


Amuah, J.A. \& Wuaku, H.M. /Use of proverbs as communicative tool in Ghanaian choral music compositions

\begin{tabular}{|c|c|c|}
\hline 'Tadodo de tef'aa megalio & No possibility of getting near there. & \\
\hline $\begin{array}{l}\text { Ne metso de dodoa dzi kaba } \\
\text { ne mehoe (x2) }\end{array}$ & $\begin{array}{l}\text { I would have uprooted it if I had taken } \\
\text { the planned action earlier (x2) }\end{array}$ & \\
\hline Etsi megbe xoxo & It's already late & \\
\hline $\begin{array}{l}\text { Etsi megbe, hezu fu nam } \\
\text { mele kpekpe }\end{array}$ & $\begin{array}{l}\text { It's late and has become a burden am } \\
\text { suffering }\end{array}$ & \\
\hline $\begin{array}{l}\text { Maalee, maalee dii } \\
\text { wonso }\end{array}$ & I will bath, I will bath, keeps one in dirt & Proverb \\
\hline $\begin{array}{l}\text { Chorus: Tso de 'dzi egbe, } \\
\text { tso de'dzi ege, tso, ne naws } \\
\text { dodoa dzi }\end{array}$ & $\begin{array}{l}\text { Chorus: Rise up today, rise up today, } \\
\text { rise up and take action as planned. }\end{array}$ & \\
\hline $\begin{array}{l}\text { Dododziwows tsotso da de } \\
\text { ggo }\end{array}$ & $\begin{array}{l}\text { Postponement of plans (procrastina- } \\
\text { tion) }\end{array}$ & \\
\hline Tsi wo tsianyi mawomaws & Leaves the plan undone & \\
\hline $\begin{array}{l}\text { Tso de 'dzi egbe, tso de 'dzi } \\
\text { egbe, tso, ne naws dodoa dzi }\end{array}$ & $\begin{array}{l}\text { Rise up today, rise up today, rise up } \\
\text { and take action as planned. }\end{array}$ & \\
\hline $\begin{array}{l}\text { Dododziwows tsotso da de } \\
\text { ggo }\end{array}$ & Postponement of plans & \\
\hline Dee wo tsianyi mawsmaws & Leaves the plan undone & \\
\hline $\begin{array}{l}\text { Solo: Tso de 'dzi egbe, tso de } \\
\text { dodoa dzi }\end{array}$ & $\begin{array}{l}\text { Solo: Rise up today, rise up to the task } \\
\text { today }\end{array}$ & \\
\hline $\begin{array}{l}\text { Chorus: Etso menye towo } \\
\text { oo }\end{array}$ & $\begin{array}{l}\text { Chorus: You don't have a hold on } \\
\text { tomorrow. }\end{array}$ & \\
\hline Solo: Egbe tuwo, wo egbe & $\begin{array}{l}\text { Solo: Today is at your disposal use } \\
\text { today. }\end{array}$ & \\
\hline $\begin{array}{l}\text { Chorus: } \\
\text { oo }\end{array}$ & $\begin{array}{l}\text { Chorus: You don't have a hold on } \\
\text { tomorrow. }\end{array}$ & \\
\hline $\begin{array}{l}\text { Solo: } \text { Mega susu be etso } \\
\text { naa nyowu oo }\end{array}$ & $\begin{array}{l}\text { Solo: Do not think tomorrow will be } \\
\text { better }\end{array}$ & \\
\hline $\begin{array}{l}\text { Chorus: Etso menye towo } \\
\text { oo }\end{array}$ & $\begin{array}{l}\text { Chorus: You don't have a hold on } \\
\text { tomorrow. }\end{array}$ & \\
\hline $\begin{array}{l}\text { Solo: Egbe tuwo, tso de } \\
\text { dodoa yu }\end{array}$ & $\begin{array}{l}\text { Solo: Today is at your disposal, rise up } \\
\text { to the task }\end{array}$ & \\
\hline $\begin{array}{l}\text { Chorus: Etso menye towo } \\
\text { oo }\end{array}$ & $\begin{array}{l}\text { Chorus: You don't have a hold on } \\
\text { tomorrow }\end{array}$ & \\
\hline Maalee, maalee, dii wonso & I will bath, I will bath, keeps you in dirt & Proverb \\
\hline $\begin{array}{l}\text { Solo: Xonye de do ame } \\
\text { dodam be mava se nye puts } \\
\text { wo nya de da }\end{array}$ & $\begin{array}{l}\text { A friend sent word inviting me for a } \\
\text { discussion in my own interest. }\end{array}$ & \\
\hline
\end{tabular}


Amuah, J.A. \& Wuaku, H.M./Legon Journal of the Humanities Vol. 30.1 (2019)

\begin{tabular}{|c|c|c|}
\hline $\begin{array}{l}\text { Mexs nyaa pe, wo dodo de } \\
\text { eyu }\end{array}$ & $\begin{array}{l}\text { I received the word alright, and } \\
\text { planned for it }\end{array}$ & \\
\hline Mews dodo be maa yi & I planned that I will go & \\
\hline Mexऽ dua p $\varepsilon$, wo dodo de eju & $\begin{array}{l}\text { I received the message alright, and } \\
\text { planned for it }\end{array}$ & \\
\hline Mews dodo be mayi, mayi, & I planned that I will go, I will go & \\
\hline $\begin{array}{l}\text { Afee woava ayi afide, ava yi } \\
\text { dude fe }\end{array}$ & Before he goes somewhere, or travels & \\
\hline Mewo dodoa pe, edziwows & $\begin{array}{l}\text { I had planned, alright, the implemen- } \\
\text { tation }\end{array}$ & \\
\hline Etso maayi, etso maa yi & I will go tomorrow, I will go tomorrow & \\
\hline Eya dzi ko mele kaka & This is what I kept telling myself & \\
\hline $\begin{array}{l}\text { Kasia masei, xonyea megali } \\
o\end{array}$ & $\begin{array}{l}\text { Suddenly, the next I heard; the friend is } \\
\text { no more }\end{array}$ & \\
\hline $\begin{array}{l}\text { Kasia masei, xonyea megali } \\
o\end{array}$ & Before I heard, that friend is no more & \\
\hline $\begin{array}{l}\text { Ne me tso kaba yi yee ne } \\
\text { metuii }\end{array}$ & $\begin{array}{l}\text { If only I arose and attended to the call, } \\
\text { I would have met him. }\end{array}$ & \\
\hline $\begin{array}{l}\text { Ne me tso kaba yi yee ne } \\
\text { metuii }\end{array}$ & $\begin{array}{l}\text { If only I arose and attended to the call, } \\
\text { I would have met him. }\end{array}$ & \\
\hline Etsi megbe xoxo & It's already late & \\
\hline $\begin{array}{l}\text { Etsi megbe hezu agba nam } \\
\text { mele tsotso }\end{array}$ & $\begin{array}{l}\text { It's too late now and has become a bur- } \\
\text { den am carrying }\end{array}$ & \\
\hline Maalee, maalee, dii wons & I will bath, I will bath, keeps you in dirt & Proverb \\
\hline $\begin{array}{l}\text { Chorus: Tso de 'dzi egbe, } \\
\text { tso de 'dzi egbe, tso, ne naws } \\
\text { dodoa dzi }\end{array}$ & $\begin{array}{l}\text { Chorus: Rise up today, rise up today, } \\
\text { rise up and take action as planned. }\end{array}$ & \\
\hline Dododziwowstsotsodadeygs & $\begin{array}{l}\text { Postponement of plans (procrastina- } \\
\text { tion) }\end{array}$ & \\
\hline Tsi wo tsianyi mawsmaws & Leaves the plan undone & \\
\hline $\begin{array}{l}\text { Tso de 'dzi egbe, tso de 'dzi } \\
\text { egbe, tso, ne naws dodoa dzi }\end{array}$ & $\begin{array}{l}\text { Rise up today, rise up today, rise up } \\
\text { and take action as planned. }\end{array}$ & \\
\hline Dododziwowstsotsodadeygs & Postponement of plans & \\
\hline Tsi wo tsianyi mawsmaws & Leaves the plan undone & \\
\hline $\begin{array}{l}\text { Solo: Tso de 'dzi egbe, tso de } \\
\text { dodoa dzi }\end{array}$ & $\begin{array}{l}\text { Solo: Rise up today, rise up to the task } \\
\text { today }\end{array}$ & \\
\hline
\end{tabular}


Amuah, J.A. \& Wuaku, H.M. /Use of proverbs as communicative tool in Ghanaian choral music compositions

\begin{tabular}{|c|c|c|}
\hline $\begin{array}{l}\text { Chorus: Etso menye towo } \\
\text { oo }\end{array}$ & $\begin{array}{l}\text { Chorus: You don't have a hold on } \\
\text { tomorrow. }\end{array}$ & \\
\hline$\frac{\text { Solo: }}{\text { yuds }}$ Egbe tuwo, ws egbe & $\begin{array}{l}\text { Solo: Today is at your disposal use } \\
\text { today. }\end{array}$ & \\
\hline$\frac{\text { Chorus: }}{\text { oo }}$ Etso menye towo & $\begin{array}{l}\text { Chorus: You don't have a hold on } \\
\text { tomorrow. }\end{array}$ & \\
\hline $\begin{array}{l}\text { Solo: } \text { Mega susu be etso } \\
\text { naa nyowu oo }\end{array}$ & $\begin{array}{l}\text { Solo: Do not think tomorrow will be } \\
\text { better }\end{array}$ & \\
\hline $\begin{array}{l}\text { Chorus: Etso menye towo } \\
\text { oo }\end{array}$ & $\begin{array}{l}\text { Chorus: You don't have a hold on } \\
\text { tomorrow. }\end{array}$ & \\
\hline $\begin{array}{l}\text { Solo: Egbe tuwo, tso de } \\
\text { dodoa } \mathrm{yu}\end{array}$ & $\begin{array}{l}\text { Solo: Today is at your disposal, rise up } \\
\text { to the task }\end{array}$ & \\
\hline Chorus: Etso menye towo & $\begin{array}{l}\text { Chorus: You don't have a hold on } \\
\text { tomorrow }\end{array}$ & \\
\hline Maalee, maalee, dii wonos & I will bath, I will bath, leaves you in dirt & Proverb \\
\hline
\end{tabular}

\section{Nunya Adidoe (Knowledge is the Baobab)}

\begin{tabular}{|c|c|c|}
\hline Ewe Text & English Translation & Proverb \\
\hline Nunya adidoe, & Knowledge is the baobab, & \multirow[b]{2}{*}{ Proverb } \\
\hline Asi me tunc $o$ & The arms' length cannot go round it & \\
\hline Nunya adidoe, & Knowledge is the baobab, & \multirow[b]{2}{*}{ Proverb } \\
\hline Asi me tunc o & The arms' length cannot go round it & \\
\hline Nunya adidoe, & Knowledge is the baobab, & \multirow[b]{2}{*}{ Proverb } \\
\hline Asi me tunc o & The arms' length cannot go round it & \\
\hline Nunya adidoe, & Knowledge is the baobab, & \multirow[b]{2}{*}{ Proverb } \\
\hline Asi me tunc o. & The arms' length cannot go round it & \\
\hline Tun $\varepsilon$ o, tun $\varepsilon$ o & $\begin{array}{l}\text { Cannot go round it, cannot go round } \\
\text { it }\end{array}$ & \\
\hline
\end{tabular}




\section{Kokjsakyi Vulture}

\begin{tabular}{|c|c|c|}
\hline Twi & English Translation & Proverbs \\
\hline 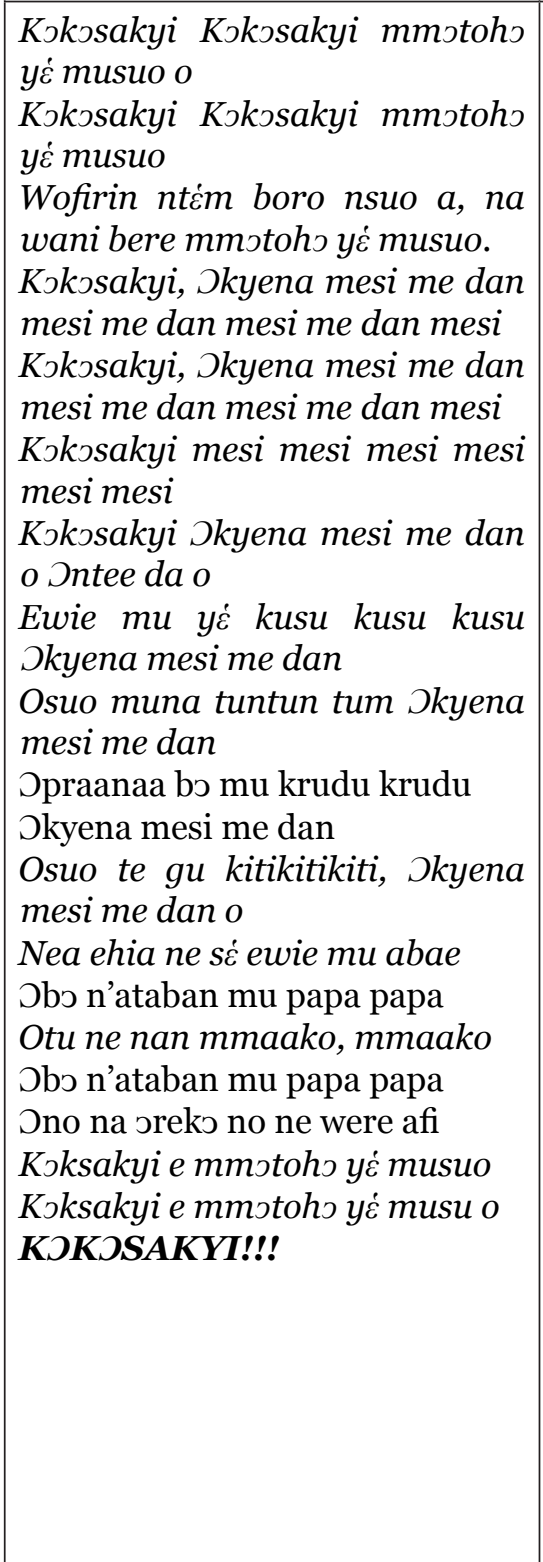 & $\begin{array}{l}\text { Vulture, vulture, procrastina- } \\
\text { tion is the thief of time } \\
\text { Vulture, vulture, procrastina- } \\
\text { tion is the thief of time } \\
\text { If you set off in good time to } \\
\text { swim you show seriousness, } \\
\text { procrastination is the thief of } \\
\text { time } \\
\text { Vulture, I will build my house } \\
\text { tomorrow, } \\
\text { I will build, I will build } \\
\text { Vulture, I will build my house } \\
\text { tomorrow, I will build, I will } \\
\text { build } \\
\text { Vulture, I will build, I will build, } \\
\text { I will build } \\
\text { Vulture, I will build my house } \\
\text { tomorrow, it is lying } \\
\text { The weather is very cloudy I } \\
\text { will build my house tomorrow } \\
\text { The rain is about to fall I will } \\
\text { build my house tomorrow } \\
\text { The thunder strikes heavily, } \\
\text { I will build my house tomorrow } \\
\text { It rains cats and dogs, I will } \\
\text { build my house tomorrow } \\
\text { All that it requires is the weath- } \\
\text { er to be clear, } \\
\text { It swings the wings } \\
\text { It takes majestic steps, } \\
\text { It swings the wings } \\
\text { It has left, it has forgotten. } \\
\text { Vulture, procrastination is the } \\
\text { thief of time } \\
\text { Vulture, procrastination is the } \\
\text { thief of time } \\
\text { VULTURE!!! }\end{array}$ & $\begin{array}{l}\text { Proverb } 1 \\
\text { Proverb } 2\end{array}$ \\
\hline
\end{tabular}




\section{Susu ho kyer $\&$ Share with others}

\begin{tabular}{|c|c|c|}
\hline Fante & English Translation & Proverb \\
\hline $\begin{array}{l}\text { Susu o, Susu W'ascm kyere o } \\
\text { Susu ho susu ho susu ho kyere }\end{array}$ & $\begin{array}{l}\text { Share, share your worries Share, } \\
\text { share, share to others }\end{array}$ & \\
\hline $\begin{array}{l}\text { Susu o, Susu W'asem kyere o, } \\
\text { Kyerc o }\end{array}$ & $\begin{array}{l}\text { Share, share your worries } \\
\text { Share }\end{array}$ & \\
\hline Itsir kor mpam o & $\begin{array}{l}\text { One head (mind) does make not a de- } \\
\text { cision }\end{array}$ & Proverb \\
\hline Adwen ntoatoa o, ntsi susu o & Minds are put together, so share & \\
\hline Susu W’ascm Kyere o & Share your worries & \\
\hline
\end{tabular}

\section{Megati Nusi Kowuwo La Fe Yoo Me Oo (Do Not Pursue Heights} Beyond You)

\begin{tabular}{|l|l|l|}
\hline Ewe Text & English Translation & Proverb \\
\hline $\begin{array}{l}\text { Megati nusi kowuwo la } \\
\text { fe yoo me oo }\end{array}$ & Do not pursue heights beyond you & Proverb 1 \\
\hline $\begin{array}{l}\text { Megati nusi kowu wo la } \\
\text { fe yoo me oo }\end{array}$ & Do not pursue heights beyond you & Proverb 1 \\
\hline $\begin{array}{l}\text { Nusiawows mee nuvodisusu } \\
\text { dzea egome tsona }\end{array}$ & $\begin{array}{l}\text { It is through this that evil thoughts set } \\
\text { off }\end{array}$ & \\
\hline $\begin{array}{l}\text { Hedoa ta puvava, fiffi, } \\
\text { amewuwu kple bubuawo } \\
\text { gbo }\end{array}$ & $\begin{array}{l}\text { Leading to envy, stealing, murder, and } \\
\text { the rest }\end{array}$ & Proverb 1 \\
\hline $\begin{array}{l}\text { Megati nusi } \text { kowuwo la } \\
\text { fe yoo me oo }\end{array}$ & Do not pursue heights beyond you \\
\hline $\begin{array}{l}\text { Esia tae lododo adewo, woli } \\
\text { tso blema, blema ke }\end{array}$ & $\begin{array}{l}\text { This is why some proverbs have lived for } \\
\text { / been there from time immemorial }\end{array}$ & \\
\hline $\begin{array}{l}\text { Nyatefe lododo adewo woli } \\
\text { tso blema blema ke }\end{array}$ & $\begin{array}{l}\text { It's true, some proverbs have lived from } \\
\text { time immemorial }\end{array}$ & \\
\hline Blema ke, (x 6) & Time immemorial, (x 6) & Proverb 2 \\
\hline Bena woanye nuxloamenya & So to serve as words of advice \\
\hline $\begin{array}{l}\text { Na dzidzimevio, na dzidzi- } \\
\text { mevio, na dzidzimevio }\end{array}$ & $\begin{array}{l}\text { For generations to come, for genera- } \\
\text { tions to come, for generations }\end{array}$ \\
\hline $\begin{array}{l}\text { Ahloe medoa nyifskpa o } \\
\text { de }\end{array}$ & $\begin{array}{l}\text { The antelope does not wear the shoes of } \\
\text { a cow }\end{array}$ & \\
\hline
\end{tabular}


Amuah, J.A. \& Wuaku, H.M./Legon Journal of the Humanities Vol. 30.1 (2019)

\begin{tabular}{|c|c|c|}
\hline $\begin{array}{l}\text { Megati nusi kowu wola fe } \\
\text { yome o }\end{array}$ & Do not pursue heights beyond you & \\
\hline $\begin{array}{l}\text { Devi mekaa nyaga o, } \\
\text { akplegae wo kana }\end{array}$ & $\begin{array}{l}\text { A child does not bite big words, it is big } \\
\text { morsel of food he bites }\end{array}$ & Proverb 3 \\
\hline $\begin{array}{l}\text { Megati nusi kowu wola fe } \\
\text { yome o }\end{array}$ & Do not pursue heights beyond you & \\
\hline $\begin{array}{l}\text { Avu du fu me duna ga o, } \\
\text { me duna ga o }\end{array}$ & $\begin{array}{l}\text { A dog does chew bones; it does not chew } \\
\text { metal, it does not chew metal }\end{array}$ & Proverb 4 \\
\hline $\begin{array}{l}\text { Megati nusi kowu wola fe } \\
\text { yome o }\end{array}$ & Do not pursue heights above you & \\
\hline $\begin{array}{l}\text { Devi gbana abobogo, } \\
\text { megbana klogo o dee }\end{array}$ & $\begin{array}{l}\text { The child breaks the shell of the snail } \\
\text { and not the shell of the tortoises }\end{array}$ & Proverb 5 \\
\hline $\begin{array}{l}\text { Megati nusi kowu wo la } \\
\text { fe yome o }\end{array}$ & Do not pursue heights beyond you & Proverb 1 \\
\hline $\begin{array}{l}\text { Devi dzroa nu, medzroa } \\
\text { golof'azi o }\end{array}$ & $\begin{array}{l}\text { A child curiously yearns for food and not } \\
\text { for the ostrich egg }\end{array}$ & Proverb 6 \\
\hline $\begin{array}{l}\text { Megati nusi kowu wo la fe } \\
\text { yome o }\end{array}$ & Do not pursue heights above you & \\
\hline $\begin{array}{l}\text { Nusiawows mee nuvodisusu } \\
\text { dzea egome tsona }\end{array}$ & $\begin{array}{l}\text { It is through this that evil thoughts set } \\
\text { off }\end{array}$ & \\
\hline $\begin{array}{l}\text { Hedoa ta yuvava, fififi, } \\
\text { amewuwu kple bubuawo } \\
\text { gbo }\end{array}$ & $\begin{array}{l}\text { Leading to envy, stealing, murder, and } \\
\text { the rest }\end{array}$ & \\
\hline $\begin{array}{l}\text { Megati nusi kowuwo la wo } \\
\text { yoo me oo }\end{array}$ & Do not pursue heights above you & \\
\hline $\begin{array}{l}\text { Ne xexeame, ne xexeame } \\
\text { nefa bskss }\end{array}$ & So the world, so the world be peaceful & \\
\hline Ne mikata mians eme. & So we all live in. & \\
\hline
\end{tabular}


Amuah, J.A. \& Wuaku, H.M. / Use of proverbs as communicative tool in Ghanaian choral music compositions

\section{Na aden? And why?}

\begin{tabular}{|c|c|c|}
\hline Twi & English Translation & Proverbs \\
\hline 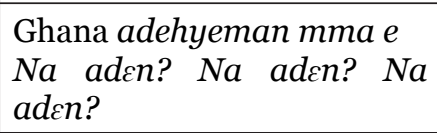 & $\begin{array}{l}\text { Ghana! A royal nationals } \\
\text { Why? Why? Why? }\end{array}$ & \\
\hline $\begin{array}{l}\text { Twe ma mentwe ne } \\
\text { mansotwe ne ntskwa dodo } \\
\text { yi firi he ni? }\end{array}$ & $\begin{array}{l}\text { Where from these struggles, countless } \\
\text { wars and arbitrations? }\end{array}$ & \\
\hline $\begin{array}{l}\text { stan hunu yi ne ntetemu mu } \\
\text { yi firi he ni? } \\
\text { Ntetemu ne animtiabuo yi } \\
\text { firi he ni? } \\
\text { Adcn na wonmmu wo nua } \\
\text { mfa no nyc hwee yi? }\end{array}$ & $\begin{array}{l}\text { Where from these divisions, sheer envy } \\
\text { and hatred, } \\
\text { Where from these divisions and } \\
\text { disrespectfulness? } \\
\text { Why don't you recognize and accord the } \\
\text { least respect to your brother/sister? }\end{array}$ & \\
\hline $\begin{array}{l}\text { Aflao kosi Elubo, Cape Coast } \\
\text { kosi Bawku Ghana krope na } \\
\text { cws ho }\end{array}$ & $\begin{array}{l}\text { Aflao to Elubo, Cape Coast to Bawku, } \\
\text { are all in the same Ghana. }\end{array}$ & \\
\hline $\begin{array}{l}\text { Nkranni sore a sse Ga nyo } \\
\text { totro ogyimi }\end{array}$ & $\begin{array}{l}\text { The Ga chests out and declares I am a } \\
\text { true Ga }\end{array}$ & \\
\hline $\begin{array}{l}\text { Nzemani sore a sse mele } \\
\text { Nzema li ikwale }\end{array}$ & $\begin{array}{l}\text { The Nzema gets up and declares I am a } \\
\text { perfect Nzema }\end{array}$ & \\
\hline Ewe ni ka sc Eweto menye & The Ewe says I am an Ewe & \\
\hline $\begin{array}{l}\text { Sefwi ni ka se menli Sefwi ni } \\
\text { paa }\end{array}$ & The Sefwi says I am a true Sefwi, & \\
\hline $\begin{array}{l}\text { Grunshini sore a, sse amo ye } \\
\text { ka sem paa }\end{array}$ & $\begin{array}{l}\text { The Grunshi declares I am a real } \\
\text { Gurunshi }\end{array}$ & \\
\hline $\begin{array}{l}\text { Angloni so } k a \text { se Anglovi } \\
\text { vava yeme nye }\end{array}$ & The Anglo also says I am true Anglo & \\
\hline $\begin{array}{l}\text { Kanjagani ka se mekabula } \\
\text { paa }\end{array}$ & The Kanjagani says I am a real Kanjagani & \\
\hline $\begin{array}{l}\text { Asanteni de ne nsa sine bo } \\
\text { Aka se meye Asanteni ba } \\
\text { kan!! }\end{array}$ & $\begin{array}{l}\text { The Asante hits his chest and says I am } \\
\text { a true Asante. }\end{array}$ & \\
\hline Enna вує den? & And so what? & \\
\hline
\end{tabular}


Amuah, J.A. \& Wuaku, H.M./Legon Journal of the Humanities Vol. 30.1 (2019)

\begin{tabular}{|c|c|c|}
\hline $\begin{array}{l}\text { Ghanani biara ye nipa se wo } \\
\text { ara } \\
\text { ono so mogya ws ne mu bio } \\
\text { o } \\
\text { Enti bu no na di no ni o } \\
\text { Do no se woara wo ho }\end{array}$ & $\begin{array}{l}\text { Every Ghanaian is as human as you are. } \\
\text { Blood equally flows in him. } \\
\text { So accord him the necessary respect and } \\
\text { love him as yourself }\end{array}$ & \\
\hline $\begin{array}{l}\text { Kae hu se } \\
\text { Tiri ko nks egyina, } \\
\text { Dua koro gye mframaa, ebu } \\
\text { Praec ws hoyi wo yi baakoa } \\
\text { na ebu } \\
\text { Woka bo mua, emmu oo, } \\
\text { Koro yع ma nkunim }\end{array}$ & $\begin{array}{l}\text { Remember that: } \\
\text { It takes two people to tango; } \\
\text { Isolated tree falls on the least } \\
\text { thunderstorm. } \\
\text { The broom breaks easily as a single } \\
\text { unit but not possible when they are put } \\
\text { together. } \\
\text { Unity brings victory. }\end{array}$ & $\begin{array}{l}\text { Proverb } 1 \\
\text { Proverb } 2 \\
\text { Proverb } 3 \\
\text { Proverb } 4\end{array}$ \\
\hline $\begin{array}{l}\text { Nea wofiri biara kasa ko a } \\
\text { woka biara } \\
\text { Enyc eno na ehia. } \\
\text { oman Ghana mpntu na ehia }\end{array}$ & $\begin{array}{l}\text { Whereever you hail from, the kind of } \\
\text { language you speak are not necessary. } \\
\text { The development of the nation Ghana is } \\
\text { the most important issue. }\end{array}$ & \\
\hline $\begin{array}{l}\text { Ycmfa ds mpagya Ghana o } \\
\text { Ghanani biara ye nipa se wo } \\
\text { ara } \\
\text { ono so mogya ws ne mu bi } \\
\text { oo } \\
\text { Enti bu no na di no nio } \\
\text { Do no se wo ara wo ho }\end{array}$ & $\begin{array}{l}\text { Let's together with love, lift the image of } \\
\text { Ghana. } \\
\text { Every Ghanaian is human as you are. } \\
\text { Blood equally flows in him. } \\
\text { So accord him the necessary respect and } \\
\text { love him as yourself. }\end{array}$ & \\
\hline
\end{tabular}

